\title{
Metaphors in the Tibetan Explanatory Tantra
}

\author{
Katharina Sabernig(D) \\ Center for Public Health, Medical University of Vienna, 1090 Vienna, Austria; \\ katharina.sabernig@meduniwien.ac.at; Tel.: +43-699-171-74725
}

Received: 20 March 2019; Accepted: 14 May 2019; Published: 28 May 2019

\begin{abstract}
The development of medical theories and concepts is not isolated from the societal "Zeitgeist" of any medical culture. Depending on the purpose and the audience addressed, different metaphors are used to explain different medical content. Doubtlessly, Tibetan medicine is associated with Tibetan Buddhism and various medical topics are linked to Buddhist knowledge. In addition to the religious link, medical texts and terms also make use of nomadic or even military metaphor. In anatomical language, metaphor and metonym are usually based on visual or morphological similarities. In the case of physiological, pathological, or therapeutic processes, metaphor often deals with dynamic and strategic elements drawn from comparisons with everyday life and other spheres of activity. These models commonly relate to specific historical and cultural backgrounds. Let us think of the European "body republic" in Renaissance medical theory or the theory of the "cell state" devised by Rudolf Virchow (1821-1902), which explains the concept of cellular pathology. Asian examples that use state functions as metaphors for the hierarchy of internal organs in Chinese and Tibetan medicine are well-known. In addition to these prominent state models, Tibetan medical language and its visual representation is rich in metaphor. In this preliminary paper not all occurring metaphors can be discussed in depth, however different types of Tibetan medical metaphor will be compared and contextualized with non-Tibetan metaphors from other contemporary and historical medical cultures.
\end{abstract}

Keywords: Tibetan medicine; medical metaphors; body republic; Buddhism; metaphorical illustrations

\section{Introduction}

Not only Tibetan and Buddhist medicine, but the entire general history of medicine is rich in metaphorical concepts, descriptions, and designations. Due to the internationalization and standardization of biomedical terminology, metaphorical designations and eponyms were banned from professional language during various debates and conferences of specific medical fields during the late nineteenth and twentieth century. Metaphors were considered unscientific and unsuitable in an empirical world view (cf.: Sappol 2017, p. 170; Van Rijn-van Tongeren 1997, p. 39). They were discredited as representing the unreal and regarded as transmitted and figurative (Johach 2008, pp. 35-41). From a less philosophical perspective, and more for practical reasons such as clear communication and comparability, experts in various medical fields created an internationally standardized terminology for anatomy and nosology. Today global health care systems apply unified international terminology such as the Terminologia Anatomica (TA) or the system of international classification of diseases (ICD 10). Nevertheless, many metaphors have survived and been created over the years as new diseases have afflicted humanity. In other cases, the origins of anatomical or diseased names have been analyzed and corrected according to their etymology as mistakes have crept in over the course of time. For example, the hip socket, acetabulum was originally named according to the similarity of its shape to an antique bowl for vinegar (latin: acetum), but medieval writers changed the name to "akzeptabulum", indicating that the socket "accepts" the femoral condyle. In this case modern 
anatomists decided to correct this error and refer to the original metonym (cf.: Michler et al. 1981, p. 17). Due to its rhetorical value, metaphor still plays a major role in creating and explaining physiological or pathological models in science, health politics, mass media, medical education as well as the physician-patient relationship. Medical metaphors have gained importance in the fields of linguistics, anthropology, history of medicine, and cognitive science. Medical professionals have become aware of the power and ethical sensitivity of metaphorical medical language (e.g., Van Rijn-van Tongeren 1997; Hanne and Hawken 2007; Johach 2008; Nie et al. 2016). Particularly in the reversibility of metaphor into a conceptual expression there is danger of abusive application, especially when the metaphor loses its therapeutic context and finds its way into politics and the media. Alarmingly negative examples of abusive metaphor borrowed from medicine and biology are anti-Semitic phantasms such as "cancer in the 'people's body'" or comparisons of humans to parasites (cf. Johach 2008, p. 317). In times of populism and rough rhetoric, it is important to be aware of the misuse of metaphor. Even within the therapeutic setting, metaphor can be helpful for some patients in aiding their understanding of a disease and therapy, in other cases metaphor can be perceived as inappropriate, even scary. James Childress wrote in the context of bioethics, "Metaphors and models may be good or bad, living or dead. Both metaphors and models can be assessed by how well they illuminate what is going on and what should go on" (Childress 1997, p. 5). I would like to stress that didactic value results from the framework in which a metaphor is applied. The meaningfulness of a metaphor depends on whether it is used for the development of scientific concepts, in medical education, in medical conversation, or in the communication of medical content in the media and politics. However, it is not in the scope of this article to elaborate on the linguistic and theoretic aspects of general metaphorology, as the complex debate on conceptuality and terminology is already well conducted (e.g., Lakoff and Johnson [1980] 2003; Haverkamp 1998; Haverkamp and Mende 2009; Polzenhagen et al. 2014).

Miscellaneous concepts of traditional Tibetan medical metaphor are well known through the respective translations of the Four Tantras (Rgyud bzhi), which is Tibet's most important medical text and attributed to G.yu-thog Yon-tan-mgon-po. ${ }^{1}$ The Illustrations to the Blue Beryl is a beautiful thangka set that accompany a famous seventeenth-century commentary to the Four Tantras (e.g., Parfionovitch et al. 1992) called Blue Beryl, compiled and authored by Sangs-rgyas-rgya-mtsho the regent of the V. Dalai Lama (Vaidūrya sngon po: Sangs-rgyas-rgya-mtsho 1973). The illustrations visually represent large parts of the Four Tantras and the commentary and the thangkas are an important part of Tibet's art-historical heritage. They are certainly a prestigious output of the fruitful time at the end of the seventeenth century, which is also called "the golden century for Tibetan medicine" (cf.: Meyer 2003, p. 99), but they do not represent the exhaustive broad medical knowledge of either the Four Tantras or the Blue Beryl. This applies in particular to the chapters on pathological issues. The Four Tantras is the short name, as the text comprises four parts. Tantra is the Sanskrit term for a weaving loom and is also a traditional Indian term for a scientific work or religious treatise. The first and shortest part - the Root Tantra (rtsa rgyud)_forms the quintessence of Tibetan medicine. The more extensive second part, the Explanatory Tantra (bshad royud), provides the preclinical foundation and is the focus of this paper. The third part, the Instructional Tantra (man ngag rgyud), is the most comprehensive and describes the clinical application of this knowledge with regards to the eight major groups of diseases. The fourth part-Subsequent Tantra (phyi ma rgyud)—explains specific diagnostic and therapeutic skills. The origin of the text dating back to at least the thirteenth century is still under discussion, best described by Yang Ga (2010). However, a distinct examination and comparison of Tibetan medical metaphor with other historical metaphors in respective to medical systems has not yet taken place. Cheryl Anne Reighter (2000) explored the structure of metaphor in contemporary Tibetan medical settings, mainly based on interviews. Her narratives are valuable, but the focus of this paper is

1 Critical edition of the Four Tantras: Bstan-vdzin-don-grub (2005); translations of the Explanatory Tantra: Dash (1994-2001); Clark (1997); Yuthok Yonten Gonpo (2008); Ploberger (2012). The complete name is: Bdud rtsi snying po yan lag brgyad pa gsang ba man ngag gi rgyud: Tantra of Secret Instructions on the Eight Branches, the Essence of the Elixir of Immortality. 
on written metaphor in classical medical literature. The Four Tantras contain two chapters which explicitly deal with metaphor. The sixth chapter of the Root Tantra uses the concept of a tree hierarchy to give structure for the content of the content of the chapters on physiopathology, diagnostics and therapeutic intervention. The three arboreal hierarchies relate to each chapter and are depicted on thangkas two, three, and four of the Illustrations to the Blue Beryl. The third chapter of the Explanatory Tantra describes "models of the body" (lus kyi vdra dpe), visually represented by thangka six. Here the locomotor system is compared with the architecture of a Tibetan temple and internal organs are embodied by the authorities of state. While arboreal and state metaphors may be regarded as the best-known metaphors of Tibetan medicine, various types of hidden metaphor can be found in many other chapters of the Explanatory Tantra. They are so numerous that of course an examination of all occurring metaphors comprised in the Explanatory Tantras is not in the scope of this work. This paper will provide an introduction to arboreal metaphor, Buddhist conceptual metaphor, selected structural metaphors for the practicing physician, metaphors relating to internal organs, as well as architectural metaphors for other body parts. In addition, metaphorical strategies for dealing with patients and their diseases and metaphorical names in the field of anatomy and pharmacology will be reviewed. These examples borrowed from different fields such as religion, nature, military, politics, or architecture will be compared with metaphor in different medical cultures in order to provide a transcultural context and to question how far these metaphors can still be applied in a modern medical system. The aim of this article is to demonstrate the variety of different forms of metaphor in Tibetan medicine by means of selected examples. Philological and linguistic aspects play a limited role.

\section{Arboreal Metaphor}

The use of the arboreal metaphor in Tibetan medicine, as described in the sixth chapter of the Explanatory Tantra, is widely known through the Illustrations to the Blue Beryl. Thangkas numbers two, three, and four depict not only the hierarchical structure of the chapters on the foundation of physiopathology, diagnostics, and therapeutic intervention, but also elaborately illustrate the content of these chapters (Parfionovitch et al. 1992, pp. 19-24). Several historical Tibetan medical scholars have written elaborate commentaries providing structure to the content of the Explanatory Tantra using the arboreal metaphor. ${ }^{2}$ The most detailed is the text Clear Essay to the Unfolded Trees to the Explanatory Tantra, with the short title Golden Spoon by Dar-mo sman-rams-pa Blo-bzang-chos-grags (1638-1710?; Blo-bzang-chos-grags 2005), who was a personal physician to the V. Dalai Lama. It is almost impossible to visualize the dense content of the Explanatory Tantra and respective trees graphically. Nevertheless, the arcade courtyard of the medical college at Labrang Monastery, in Gansu province presents murals which depict the hierarchical structure of all chapters of the Explanatory Tantra based on Blo-bzang-chos-grags text. In order to deal with the huge quantity of information listed in the text, the authorities of the medical college have applied a visual trick. The trees do not depict specific medical content, but serve symbolically as placeholders for specific content, and show the structure of the chapters like a mind map. Trunks and branches divide each chapter into subchapters and the leaves stand for specific medical content, such as a certain pathology, a pharmacological ingredient, or medical strategy. If the number of medical items is too numerous to be depicted, the authorities of the medical college have advised the painter to use different types of leaves: a five-fingered green leaf stands for a single item; a grayish feathered leaf stands for ten items; and a colorless, wavy leaf, similar in form to an oak leaf, for a hundred items such as medical ingredients, anatomical structures, or pathologies. The extraordinary physician's achievement has meanwhile been recognized in China and a revised version of Blo-bzang-chos-grags's text with a Chinese translation accompanied by the renovated images in the Medical College at Labrang Monastery has been published (Blo-bzang-chos-grags 2017; for more information on the Labrang tree-murals, see Sabernig (2014), my dissertation: (2017a), and forthcoming:

2 E.g., Blo-bzang-chos-grags (2005); Pad-ma-dkar-po (2007; 1527-92?); or Mkhyen-rab-nor-bu and Byams-pa-phrin-las (1987). 
(2019a)). The Tibetan word for an arboreal metaphor is sdong vgrems, literally "spreading trunk", and is often translated as "unfolded tree". Both translations suggest that the mnemotechnic device not only represents static knowledge but has an inherent didactic dynamic depending on the focus of the viewer. While the trunks and branches provide an overview, the spreading leaves go into details, whereby leaves symbolizing ten or even a hundred items open up another box of knowledge. With the help of the arboreal metaphor chapters may be divided, subdivided and sub-subdivided. Audrey Prost describes the tree metaphors as "lists within lists" (Prost 2008, p. 105). As shown below, in some cases the leaves of a particular branch may represent a new chapter or subchapter in which the name of a leaf constitutes an entire branch bearing further leaves. Although the tree metaphor is highly popular in Tibetan medicine, Buddhism, didactics and in the organization of Tibetan grammar (Bkra-shis-dpal-ldan 1985; Sabernig 2017a), it cannot be regarded as a Tibetan invention as it can be found in various East Mediterranean medieval medical texts (e.g., Demaitre 2012, pp. 22-25; Savage Smith 2002, p. 122; Pormann and Savage-Smith 2007, pp. 13-15; Sabernig 2019a). An exceptionally beautiful example of an East Mediterranean arboreal hierarchy is the thirteenth century isagoge based on Iohannitius works (Hunayn ibn Ishaq al-Ibadi; 808-873; see Demaitre 2012, pp. 24-25), translations of Galenic medicine into Arabic language.

\section{Buddhist Metaphor}

It is no secret that the "architecture" of the Four Tantras as a whole is embedded in a Buddhist framework and each of its chapters is framed as a request from the hermit sage Manasija (Yid-las-skyes; as the embodiment of Amitābha), taught by Bhaișajaguru, the "medicine Buddha". Buddhist philosophy makes strong use of figurative language and Buddhist thinkers extensively consider the role of metaphor in illustrating religious concepts, as demonstrated at length by Roy Tzohar (2018). The historical connection between the Buddhist state and the development of Tibetan medicine was discussed in detail by Janet Gyatso (2015). Even though the frame story suggests that the Four Tantras are an authoritative text that can be traced back to Buddha himself, the Four Tantras are not incorporated in the canon of Buddhist literature (Kanjur and Tanjur). Most Tibetans would state that the Four Tantras are a Buddhist text or even, that the Four Tantras may be considered the words of Buddha. Buddhist wisdom and symbols are present throughout the text, such as the rules of conduct for a physician and patient; nevertheless, on a deeper textual level, religion is of lesser importance since the main medical content is independent of Buddhist concepts.

To explore the question of the extent to which the Four Tantras are entangled with Buddhist metaphor I want to apply Pierce Salguero's considerations on conceptual metaphors in Buddhist medical texts. Conceptual metaphors were first explored and defined by George Lakoff and Mark Johnson (Lakoff and Johnson [1980] 2003). Pierce Salguero identified five metaphors that are pervasive in Buddhist medical writings: "(1) The body is a collection of parts, (2) health and disease are rewards and retributions (3) the Dharma is medicine, (4) deities are healers and (5) healing is an occult power" (Salguero 2014, p. 68).

According to Salguero, the first metaphor, "the body is a collection of parts", refers to the deconstruction, subdivision, and subjection of the body in Buddhist thought and he mentions a shared feature of Buddhist descriptions of the body which are organized as lists of body parts (Salguero 2014, pp. 70-71). This feature also applies to Tibetan medicine. The fourth chapter of the Explanatory Tantra is on anatomy or the condition of the body (lus kyi gnas lugs). The chapter itself is divided into four subchapters, which provide the count of body parts connected to certain tissues without listing the concrete names of these parts, however all major commentaries comprise extensive lists of specific body parts (for more details see Sabernig 2017a, 2017b, or the Tibetan commentaries such as Sangs-rgyas-rgya-mtsho 1973, pp. 142/6-184/5; Blo-gros-rgyal-po 2005, pp. 196/18-251/16; Blo-bzang-chos-grags 2005, pp. 12/3-29/9; Pad-ma-dkar-po 2007, pp. 225/6-233/5; Ye-shes-bzang-po 2007). These lists form the "lists within lists" mentioned in the section on arboreal metaphors. Although these lists of body parts are typical for Buddhist medical texts, similar but 
not identical lists can be found in Ayurvedic texts such as the surgical treatise Suśruta-saṃitā (Priya vrat sharma 2000, pp. 170-83). Salguero also refers to the broader concept of the body as a collection of elements. In Tibetan culture the predominant system of such elements consists of five elements (vbyung ba lnga), water, fire, earth, wind, and space. Although these are an inherent part of Buddhist philosophy, they cannot be regarded as specifically Buddhist, as similar modes of "elemental" thinking are part of ancient Greek and pre-Islamic or Ayurvedic medical systems. On closer examination it becomes clear that these five elements are connected to medicine primarily through its theoretical or religious superstructure rather than concretely dealing with the etiology or treatment of a disease. They play a significant role in the Tibetan and Buddhist view of the conception of the embryo (chapter two) and the stages of death (chapter seven). In other chapters of the Explanatory Tantra they do not play a significant role except in the formation of the taste of medicines and food. In the chapter on pulse examination in the Subsequent Tantra also the five Chinese elements-water, fire, earth, wood, and metal—are also used, (e.g., Parfionovitch et al. 1992, pp. 293, 301; Yuthok Yonten Gonpo 2011, p. 18; Yang Ga 2010, pp. 242-46). Different concepts regarding the dynamics of the five elements exist side by side in traditional Chinese medicine (cf.: Sabernig 2002). They can be found in Buddhist as well as Confucian or Taoist medical traditions. Lists of body parts and reference to the elements can be found in Tibetan medicine. This is by no means a contradiction to the first Buddhist metaphor "the body is a collection of body parts" but in my opinion is not yet proof of a Buddhist text, because both can also be found in non-Buddhist medical cultures.

The second Buddhist metaphor according to Salguero states that "health and disease are rewards and retributions." Is this view of the saluto- and pathogenesis characteristic for the Four Tantras? Closely connected to the theory of elements is the concept of humoral pathology. ${ }^{3}$ Similar to the basic theory of Ayurveda and Islamic Unani medicine on the Subcontinent or historical Byzantine medicine, Tibetan medicine contains the concept of body humors which should be in balance with each other in order to remain in a state of health. This condition is called eucrasia. In the Tibetan case the three humors (nyes pa gsum) are called bad-kan, commonly translated as phlegm; $m$ khris-pa, commonly translated as bile; and rlung, commonly translated as wind. The translation of these terms should not be taken literally as they are embedded in a metaphorical framework rich in subtle, physical and metaphysical analogies. The Tibetan humors are based on the concept of the tridoșa in Ayurveda where phlegm corresponds to kapha, bile to pitta and wind to vāta. However, in Ayurveda a bodily humor may also have a positive notion in the case of balance and only be regarded as pathological in the case of imbalance, or dyscrasia. In Tibetan medicine the pessimistic view of Buddhism is incorporated in the humoral concept and the term nyes-pa simply means fault (see: Meyer 1995, p. 128). In Tibetan medicine-as well as Indian and Chinese Buddhist medical texts (cf.: Salguero 2010, p. 69)-the etiology of a humoral disease is overtly linked to the Buddhist "three faults" —-delusion, hatred, and desire-as described in chapter three of the Root Tantra or in chapter eight of the Explanatory Tantra (Bstan-vdzin-don-grub 2005, pp. 13/4, 41/15). In the Illustrations to the Blue Beryl the "three poisons" are additionally depicted by their traditional animal symbols: pig, snake, and bird, respectively (see: Parfionovitch et al. 1992, pp. 20, 176 no. 43; 54, 209 no. 4-6).

The connection to Buddhism is clear but in the context of the five chapters on pathology this forms a relatively small part. In addition to this religiously associated "cause" (rgyu) for a disease there are further concepts which are regarded as trigger factors ( $r k y e n)$ such as time, demons, nutrition and behavior as described in chapter nine of the Explanatory Tantra. The "tree of nosology" depicting the structure of the chapter on the classification of diseases (chapter twelve), which is the most comprehensive chapter of the Explanatory Tantra with regard to pathology, is divided into three trunks,

3 The author is aware that the term "humoral pathology" in the context of Asian medicines is discussed controversially because it is originally connected to ancient Greek medicine, nevertheless, in a broader context most traditional medical concepts makes use of humoral or subtle energies which should relate to a state of balance as well as a more corpuscular description of disease, generally known as solidar pathology. 
categorized according to the "cause" of diseases, the "basis" (rten) of the medical classification and, thirdly, according to the variety of appearances of individual pathologies or types (rnam pa; for more details see Sabernig 2017a, 2019a). The "cause" is certainly connected to the second Buddhist medical metaphor but the larger part, the "basis," classifies 404 diseases, which are only superficially associated with Buddhist theory. In both Ayurvedic and Chinese Buddhist medical cultures, the 404 diseases are often explained as the 101 pathological conditions associated with each of the three "faults" and the final 101 as their combination (Salguero 2010, p. 58) or as the 101 ailments relating to the "elements" earth, water, fire, and wind (e.g., Unschuld 1980, p. 107), a connection to the first metaphor. However, in Tibetan medicine the 404 pathologies have little to do with these broader concepts, as each of the 404 conditions is classified accurately. They are listed individually in the Explanatory Tantra and in more detail in its commentaries (Bstan-vdzin-don-grub 2005, pp. 62/16-66/17; Sangs-rgyas-rgya-mtsho 1973, pp. 289/5-302/5; Blo-gros-rgyal-po 2005, pp. 431/10-458/5). The most detailed accompanying text to this passage is again the text by Blo-bzang-chos-grags (2005, pp. 47/14-63/16). The majority of this "trunk" deals with empirical and somatic pathologies, classified according to humoral as well as solidar pathological thinking involving local and systemic pathological conditions as they can be found in many traditional medical cultures. It can be summarized that Buddhist ideas of pathogenesis are integrated and prominently placed, but the majority of ailments mentioned are to be considered in light of protoscientific medical ideas.

The third metaphor "the Dharma is medicine" plays an important role in spiritual Tibetan healing culture, meaning the Buddhist doctrine is regarded as medicine. "The Dharma is medicine" is a broad topic and can only be touched superficially in this article. According to Buddhist convention the four kinds of suffering — birth, old age, disease, and death—are regarded as the four principal afflictions of humanity. To relieve suffering caused by old age and disease is a core element of any medical culture with the aim to classify and treat these conditions. Birth and death are part of everyday hospital life nowadays but this is a relatively modern phenomenon. The nature of conception, embryology, birth, and death as well as life beyond death is traditionally more difficult to perceive and is usually strongly connected to a religious and cultural background. Frances Garrett even concluded that "embryology appears to have become a place for medical writers to do a bit of philosophizing" (Garrett 2007, p. 422). Therefore, it is not surprising that the chapters on embryology and death, chapters two and seven of the Explanatory Tantra involve the five elements, which are essential components of Buddhist philosophy. Even if these chapters show a stronger influence of Buddhist philosophy, Garrett states that "embryological accounts in religious texts are often different in both structure and content than those found in medical texts" (Garrett 2007, p. 414). Religion and medicine have different intellectual approaches; nevertheless, medical activity per se aims to relieve suffering, and is considered to be in utmost harmony with the ideal of Dharma. Coping with birth and death is an existential experience of any human individual and universally much more influenced by religious and cultural consideration than the treatment of curable disease based on medical evidence. Many modern medical universities (such as Medical Universities of Vienna) nowadays include teachings in various religious and cultural aspects of old age, disease, and death. To understand religious concepts and coping strategies of patients dealing with their illness and eventual death is one aspect of professional medicine, the application of religious practice in medical practice is another, and remains a very individual decision for a practicing physician.

\section{The Practicing Physician}

The fourth and fifth Buddhist medical metaphors state that "deities are healers" and "healing is an occult power." Both metaphors imply subtle healing vehicles, either in the form of deities', powerful healing skills, even of the Buddha himself as healer, or in the form of an occult power that the healer or religious practitioner is able to make use of. While religious texts on tantric Buddhist healing focus on the latter, the Four Tantras only incorporate the idea superficially, but also involve many other modes of therapeutic skill. The frame story of the Four Tantras describes the perfect condition 
for successful medical teaching as presented in the introductory chapter. Located directly in the center of the mythical medical city Lta-na-sdug the throne is reserved for Bhaisajaguru, the "medicine Buddha" (for more details on the mythical medical city see Parfionovitch et al. 1992, pp. 17-8; Gyatso 2015, pp. 147-48; Sabernig 2018). Nevertheless, even in Tibetan medicine the complexity of medical professions requires several types of metaphor; religion respectively Buddhism, is only one way to convey an image of the ideal character of a healer. In Tibetan medicine the "practicing physician" is described in the 31st chapter of the Explanatory Tantra. Unlike most other chapters of the text, it is full of Buddhist ideals and mundane rules of conduct that a good doctor should follow, for instance Tibetan doctors are required to recite Buddhist medical mantras. The arboreal structure of this chapter consists of six trunks, the largest first trunk deals with preconditions of becoming a practicing physician such as being able to read and write, respecting the teacher or obeying the vow. In the context of worldly affairs, the commentaries specify the root text as follows: "The physician should serve the needy people in word and deed as a friend (gnyen po)" and some lines below, "the physician is a bodhisattva (byang chub sems dpav) when one pays particular compassion to sick people, ordinary and poor people" (rudimentary in the Four Tantras: Bstan-vdzin-don-grub 2005, p. 144/3-7; and formulated in more detail in the almost identical commentaries: Sangs-rgyas-rgya-mtsho 1973, pp. 632/3-633/1; Blo-bzang-chos-grags 2005, p. 131/3-10; Blo-gros-rgyal-po 2005, p. 885/7-24). In the Buddhist context the terms "friend" and "bodhisattva" are probably not too far apart, and good physicians should prove themselves in both roles. The second trunk only summarizes the major coordinates of medical knowledge, but the third trunk explains the term "physician" (sman pa). A physician is described as a hero or heroic (dpav $b a$ ) because he/she is able to perform surgery "in the case of a major illness and is not discouraged while examining [the body] with a spoon (surgical probe) and incision as well as excision" 4 . The physician is also called "father" ( $p h a)$ for protecting sentient beings and the "king's master" (lha rje) (rudimentary in the Four Tantrass: Bstan-vdzin-don-grub 2005; and in more detail in the almost identical commentaries: Sangs-rgyas-rgya-mtsho 1973, p. 634/3-4; Blo-bzang-chos-grags 2005, p. 132/10-18; Blo-gros-rgyal-po 2005, p. 887/7-12). During the era of the Tibetan Monarchy, tha rje was already coined as a term for a "court physician" also translated as "Lord of Gods" by Emperor Khri-srong-lde-btsan (cf.: BGT 1985, p. 3081). The term can be found in various old Tibetan texts available via the database "Old Tibetan Documents Online" ${ }^{5}$ but I could not find a particular Sanskrit equivalent for tha rje in a Tibetan-Sanskrit Dictionary (cf.: Chandra 1959-1961; Negi Jita Sain 1993-2005). Although mentioned in all major commentaries, the respective thangka does not represent the diversity of exemplary role models. Instead almost half of the thangka depicts different types of pathogenic demons and meditational deities which are only briefly mentioned in the root text. In this case, Blo-bzang-chos-grags refers to them solely in keywords (Blo-bzang-chos-grags 2005, p. 127/12-18), but the passage on subtle pathogenic influences is explained in great detail in the major commentaries. However, the major commentaries refer mainly to pathogenic deities rather than healing deities (Sangs-rgyas-rgya-mtsho 1973, pp. 614/4-628/6; Blo-gros-rgyal-po 2005, pp. 887/18-882/6). Although the commentaries are identical in relation to longer passages, they differ in various details. The commentary by the sharp-minded surgeon Blo-bzang-chos-grags, who was also the medical director of the prestigious Medical College at Iron Hill (lcags po ri) in Lhasa, is generally characterized by the omission of religious and philosophical aspects whereas the passages on more empirical medical core topics, such as anatomy, pathology, pharmacology, or therapeutic skills, are elaborated upon extensively. Then again, the commentator to the Blue Beryl, Sangs-rgyas-rgya-mtsho, never became a physician himself and had more political and religious responsibility than medical practice. For a longer examination of the history of the Blue Beryl please refer to the contribution by Olaf Czaja (2007).

4 The surgical treatment is described as vdral gcod meaning "incision" (vdral ba) and "excision" (gcod pa). Please note that the term surgery should not be read in the biomedical sense but with regard to its etymology: "working or done by hand".

5 https://otdo.aa-ken.jp/search/ 10.05.2019: 18:45. 
The fourth trunk of the tree of the practicing physician classifies medical professionals according to their status. The unsurpassable physician is equated with the true Buddha, the sublime. Aside from this idealized form, physicians are categorized as either special or ordinary. The characteristics of both types also correspond to Buddhist ideals. Their qualification is based on Buddhist rules of conduct, but does not use metaphor; nevertheless, the symbolism is similar to the idea of priesthood. While there are no other metaphors for the skills and behavior of the "best" of the ordinary physicians, there are a series of conceptual metaphors used to demonstrate the characteristics of the "worst" physician which are vividly depicted on the thangka (e.g., Parfionovitch et al. 1992, p. 245 no. 37-61). In Tibetan culture an education, in particular "authentic lineage", plays a significant role and was described in traditional works on the history of Tibetan medicine (cf. Taube 1981; Gyatso 2015, p. 379). Therefore, the first and most referred to metaphor in the Explanatory Tantra is the comparison of a physician without such lineage to a fox seizing a king's throne. Behind such questions of lineage and status, and the absence of various practical and theoretical skills, is compared to various situations in Tibetan life borrowed from practical, social, agricultural, or military analogies. An example of a practical metaphor is the comparison of a physician who does not understand the meaning of medical treatises with a blind person to whom materials are shown. An example of a social metaphor is the comparison of a physician who does not understand diagnostic methods with a vagabond who lingers abroad without relatives. An agricultural metaphor is the comparison of a physician who is not able to prepare pacifying medical compounds with a farmer who does not know how to cultivate a field. An example of a military metaphor is the comparison of a physician who has no surgical instrument to a hero without harness and weapons (Bstan-vdzin-don-grub 2005, pp. 144/20-145/19). Blo-bzang-chos-grags does not give much attention to the smaller metaphors related to a lack of specific therapeutic skills, but does comment rather drastically but in alignment with other major commentaries, using a "wrap up metaphor" for these bad physicians: "As far as these miserable doctors are concerned, their wrong understanding of serious and minor illnesses certainly leads to their treatment being wrong. That is why they are the 'lords of hell', [such a physician is] a demon who uses the medical instruments of a doctor to swing the noose of the 'lord of death' in the name of the "lords of the gods'" (Sangs-rgyas-rgya-mtsho 1973, pp. 638/6-639/1; Blo-gros-rgyal-po 2005, p. 891/19-22; Blo-bzang-chos-grags 2005, p. 135/4-7). The expressions "lord of hell" (vchi bdag), "lord of death" (gshin rje), and "lord of the gods" (lha rje) would be understandable in an Abrahamic or ancient Greek context, too, but the terms for bad physicians can be connected with the Indian Pantheon. The "lord of death" corresponds to Yama (Yamäntaka; cf.: Cornu 2006, p. 721) and the "lord of hell" to mrtyumāra (Cornu 2006, p. 840). However, the "lord of the gods" seems to be an old and genuine Tibetan term (cf. above) to associate physicians with gods, and is reminiscent of the popular German expression "Götter in Weiß" (gods in white) for doctors.

Since a physician is compared with a bodhisattva the definition complies with the fourth Buddhist medical metaphor. It is clear that in many cases the thangkas depict Buddhist symbols, as mentioned in the Four Tantras and its commentaries, and they present medical content in a religious framework. Although the Buddhist context is obvious, as Janet Gyatso pointed out they are not painted from a completely Buddhist perspective because religious details are not depicted in as elaborated manner as in purely religious paintings and many laical details of the daily life of ordinary people are illustrated vividly (cf.: Gyatso 2014, p. 209f; 2015, pp. 48-49).

Beyond this religious aspect we learn that physicians of Tibetan medicine are also expected to act as a "friend" and "father figure" as well as a "hero" and even as a "divine sir". Are there similar pictures in today's medical practice? In the context of biomedicine Carlos D. Tajer presents multiple structural metaphors and states "medicine is a war, an art, [ ... ] priesthood, the space where a suffering person and another one who intends to help him meet" or, from a technical perspective, he compares the relationship between a doctor and a patient with that of a mechanic repairing a car (Tajer 2012, p. 487). In Tajer's contemporary essay, a physician is compared with a warrior, an artist, a priest, a mechanic, or someone who intends to help. Another multilayered picture is the metaphor of "the physician as 
the captain of a ship", which is the title of a book including contributions on the complex relationship between physicians and their patients, and other aspects in the healthcare system (King et al. 1988). Albert Howard Carter not only collected different images portraying physicians but also discussed the influence of different role models on the physician-patient relationship. He takes up Williams F. May's reflections, who argued that less helpful images would be "parent", "fighter", and "technician", while the best would be "teacher" (Carter 1989, p. 159). He sets this assessment against the proportion of responsibility between physician and patient. In the case of surgery or critical care the physician bears much responsibility and behaves in the role of a "fix-it man", "mechanic", or a "repair person". One may add a "plumber". In the scope of a physical examination or minor illness patient and physicians would rather communicate as "partners", colleagues", or "collaborators", while the patient's change of lifestyle, such as smoking cessation or weight control, would be accompanied by the physician in the role of a "coach", "teacher", or "performer" (Carter 1989, pp. 160-61). In this case the responsibility for successful development lies with the patient. In clinical practice a good physician has to switch between these models from situation to situation and patient to patient.

To apply Tibetan metaphors, in the acute stage of an emergency a physician may appear in the role of a bodhisattva who just managed to save a life by being a hero because the surgeon was able to bravely intervene and perform surgery. In modern medicine the same surgeon/physician who acted courageous as a "hero" during an emergency intervention or treatment of a severe disease would communicate with the same patient rather as teacher or coach during the stage of convalescence and rehabilitation and maybe also in the role of a friend during an aftercare check-up.

In Tibetan medicine there are not many metaphors indicating a flat hierarchy in the physician-patient relationship. The "friend" metaphor symbolizes equality but most other images demonstrate a strong hierarchy, which is not surprising as flat hierarchies in the physician-patient relationship are generally a relatively new development. They are more often demanded by the patient and often associated with the desire for autonomy. However, the term "friend" has a different connotation in Tibetan language than in European languages. The term "fried" (gnyen po) also stands, inter alia, for helper, assistant, remedy, or antidote (cf.: Jaschke [1881] 2003, p. 193). The friendship model has already raised discussions among scholars of medical humanities (e.g., Siegler 1997, pp. 47-48). The sensitive situation in the doctor-patient relationship is also due to the fact that patients often show themselves to be more personal and vulnerable in a therapeutic setting than in an established friendship, while on the other hand the doctor is paid for his work, the treatment of the condition is part of everyday life, and the personal vulnerability of the doctor is not under consideration.

The "father figure", a paternal or parental model, symbolizes the protective and compassionate nature of an older family member where the child may be treated as an infant or an adult. This paternal model which includes moral authority may be found in many medical cultures, nevertheless it is a model that allows little patient autonomy and the responsibility lies much more on the side of the physician. Janet Gyatso stressed a historical Tibetan discussion that it would be vital for a physician to be able to build up confidence of the community and that necessity of self-promotion and competitiveness among physicians to gain fame and fortune may be misunderstood or misused (Gyatso 2015, pp. 379-80). The "hero" and "divine sir" or "lord of god" demonstrates distance and power, even healing power, which may open up anonymous space for healing but stands for an asymmetrical relationship where misconduct will have severe consequences. Tibetan commentators were aware of this problem as the example of unskilled physicians compared to the "lord of death" demonstrates. Mark Siegler refers the context of these asymmetric relationships to an older variant of this hierarchic form—the priest-penitent relationship (Siegler 1997, p. 45).

\section{Internal Organs and State Authorities}

In the first part of the chapter on the "models of the body" the locomotor system of the human body is compared with the architecture of a Tibetan temple or even the palace of a universal emperor. In the second part of the chapter, internal organs are equated with the functions of important representatives 
of Tibetan aristocracy. At the end, the Explanatory Tantra states with one line that vulnerable parts ${ }^{6}$ of the body are regarded as "important envoys deployed by the king" (Yuthok Yonten Gonpo 2008, p. 57; Parfionovitch et al. 1992, p. 183). Although the concepts are difficult to separate, the architectural metaphor including other structures compared to objects of everyday life will be discussed in more detail in a later paragraph.

In Tibetan medicine the human body is compared to a kingdom where the major internal organs take the role of the most important representatives of state. While the so-called solid internal organs (don: heart, lungs, liver, spleen, and kidneys) are equated with the functions of state or the leading members of the aristocracy, the "vessel" organs (snod: stomach, large, and small intestines, gallbladder and urinary bladder, and a somewhat mysterious organ called bsam sevu) are compared with everyday objects. As these organs are compared to items of furniture, they will be introduced in the paragraph on architectural metaphor. We will see that the organ metaphor of state authorities is not specifically Tibetan. Similar metaphors exist in other medical cultures, but are there any specifically Tibetan features?

The heart, regarded as the most important organ is equated with the enthroned king (rgyal po). The lung is known to consist of ten lobes whereby the five posterior lobes of the lungs represent home ministers, and the five anterior lobes of the lung represent princes or princesses. The liver is compared with the senior queen, the spleen with the junior queen and the kidneys stand for the foreign minister or beam-lifting athletes (e.g., Parfionovitch et al. 1992, pp. 27, 183; Bstan-vdzin-don-grub 2005, p. 33/14-19). The Chinese analogy based on the eighth chapter of the Inner Canon of the Yellow Emperor (Huangdi Neijing, shortly called Inner Canon) is strikingly similar. In the Chinese tradition the human body is compared with a country whose "Supreme Lord" or "monarch" is associated with the heart, the lungs with an official who has internal connections, the liver with a military official, the spleen with an official who controls barns for the storage of cereals, and the kidneys are regarded as the "enforcer" or "activator" (Vercammen 1995, p. 165). The extent and mode of the translation of Chinese medical texts into Tibetan is still under discussion (Taube 1981; Yang Ga 2010), but Yang Ga "strongly suggests that the source of this chapter might be a text that has been influenced by Huangdi neijing, or perhaps a Tibetan translation of Huangdi neijing itself" (Yang Ga 2010, pp. 157-58). A crucial difference is the explicit use of female aristocratic representatives such as the senior queen instead of a military official representing the liver and the junior queen instead of a state official. While the major commentaries relate the information in the root text in a more prosaic manner (Blo-gros-rgyal-po 2005, pp. 193/7-196/17; Sangs-rgyas-rgya-mtsho 1973, pp. 140/2-142/6), the historical authors who structured the Explanatory Tantra in the form of the arboreal metaphor only mention their existence but do not give any details of these metaphors (Blo-bzang-chos-grags 2005, pp. 11/21-12/2; Pad-ma-dkar-po 2007, p. 225). As we will see later, the significance of metaphor is often controversially assessed within various medical cultures.

Are there similar metaphors in other medical traditions? It is not in the scope of this paper to examine metaphors for all internal organs; therefore, I will concentrate on examples related to the one placed at the top of the hierarchy: the heart compared with a king. Is this a cross-cultural medical metaphor? Although the "representatives of a state metaphor" may be borrowed from Chinese sources, in the Tibetan case and Buddhist practice the heart plays a key role in classical anatomical discussions and even more in connection to tantric channels. These channels and the entrance of mind were described in great detail by Janet Gyatso (2015, pp. 251-64). Nevertheless, not only in Tibetan medicine, but also in Chinese medicine the heart and not the brain is the seat of the mind, called shen.

However, as Pierce Salguero pointed out, it is beyond question that the transmission and reception of foreign knowledge requires an analysis of the degree to which the "fit" between the source and the target terminology is close (cf.: Salguero 2010, p. 70). The use of metaphor in medical traditions,

6 For more details on vulnerable part see Sabernig (2017a, 2017b). 
their literal definition and translation depends on the context. Depending on whom the metaphor is directed, figurative expression and even more its visual representation may be of great didactic value, as the following examples from Japan will demonstrate. Around 1850, during the Edo period, two block prints were made to educate ordinary people about the interior of the body and to protect them from excessive eating or drinking and sexual intercourse. Inshoku yojo kagami (Rules of Dietary Life) and Boji yojo kagami (Rules of Sexual Life) present images of a man and a woman, which show the topography of internal organs in the tradition of a Sino-Japanese anatomical depiction although modern western influences are also recognizable. A closer look reveals the function of the organs by means of depicted scenes of the daily working life of men in a city (Rules of Dietary Life) or courtesans of in brothel (Rules of Sexual Life; see Shirasugi 2007). The image intends to protect people from excessive eating or drinking, and presents the heart in line with the Tibetan or Chinese model, as a place where an important personality sits before genuflecting subordinates and from where other people spread information via different channels. In the context of the Boji yojo kagami (Rules of Sexual Life) the inner organs are situated in the context of a brothel and the proprietress of the brothel is located at the heart. A major difference to the Tibetan and Chinese model is that ordinary miniature people inside the body are involved in the demonstration of the functions of respective internal organs.

What about European metaphors of internal organs? Josep Lluis Barona has analyzed a number of renaissance medical texts, notably the writings of the Spanish renaissance anatomist Bernardino Montaña de Monserrate (1480-1558). In a nutshell, Montaña's metaphor of the body is based on Galenic medicine, it consists of a plan by an "architect" - the genitive spirit-wherein the stove of a fortification resembles the heart distributing heat to warm up the body, the stomach is compared to a kitchen, the liver serves as a copper sideboard, and the kidneys beneath this sideboard are described as small chambers (Barona 1993, pp. 169-72). Josep Lluis Barona writes that archetypes used to justify the human body as a natural order were often closely connected to the social structure, political order and hierarchical organization of the Catholic Church (Barona 1993, p. 174). According to Barona, the Italian Renaissance physician Andrea Cesalpino (1519-1603), stated that "the soul (anima) should take the place of the king and the heart would be its venue." Further, a few decades later the physician William Harvey (1578-1657), who is regarded to have described systemic blood circulation completely for the first time, stated "the king is the foundation of his kingdom, the sun of his microcosmos, the heart of his commonwealth" (see Barona 1993, p. 175). Even today the importance of the heart plays a major role when it comes to the assessment of reconcilableness of organ transplantation with religion because the cessation of heartbeat is often seen as a precondition to define death; for example, an ultra-Orthodox Jewish perspective may regard brain death as not sufficient, while cardiac death allows only a limited number of donations (cf. Oliver et al. 2011, p. 4).

\section{Architectural Metaphors}

Aside from organs, the body consists of connective and supportive tissue, which is compared to architectural structures in Tibetan medicine. In the Illustrations to the Blue Beryl the architectural details are demonstrated as a Tibetan Monastery with white walls, black framed windows, and red elements (see Parfionovitch et al. 1992, p. 27). In this thangka, the head is compared with a turret or the uppermost shrine whose windows symbolize the opening of the sense organs decorated with Tibetan features such as a Garuda's head (khyung mgo), the upper and the lower trunk corresponds to the upper and lower courtyards. Other examples are the correspondence of hipbones to the foundations of a wall, ribs to the rafters, costal cartilages to brackets and the breast bone to a cross beam. The most important channel of life (srog rtsa nag po) is symbolized by an agate pillar (Bstan-vdzin-don-grub 2005, p. 33/4-13). Anatomically, the structure is often identified as the aorta but the identification of the term is still controversially discussed (see Gyatso 2015, p. 203). The vertebrae are compared with a stack of gold coins. The remaining "vessel" organs are compared to everyday containers found in an ordinary home. The stomach is compared to a cooking pot, the gallbladder to a sack of spices, the 
urinary bladder to a filled water jar and the unidentifiable "reservoir for reproductive fluid" called bsam sevu is regarded as a "treasure store of gems" (Parfionovitch et al. 1992, p. 183).

The artistic implementation of the Illustrations to the Blue Beryl corresponds to the style of Tibetan culture in the eighteenth century and although the text of the Four Tantras was compiled several hundred years earlier, the idea of comparing the human body to a house, a catholic church or even a city can be found in various medical cultures. I mentioned Josep Lluis Barona's essay where he found comparisons of the human body to a church, a city, a fortress or a simple house whose rooms are represented by internal organs. Even Andreas Vesalius (1514-1564), who is regarded as the founder of modern anatomy and known for his criticism of Galen's anatomical teachings, compared the skeleton to "the walls and supportive beams of a house"7. A magnificent illustration of the human body compared to a house can be found in the Hebrew medical treatise $M a^{\prime} a s e h$ Tuviyah by Tobias Cohen published 1708 in Venice. Similar to the uppermost shrine in the Tibetan thangka the highest room located in the house corresponds to the head and the windows are equated with the opening of the sense organs. The kitchen, resembling the stomach and the epigastric region between the costal arch and subcostal plane, is situated right in the middle of the house, designed as an open arcade. The floor above is protected by walls wherein the "master of the house" — the heart-resides (cf. Lepicard 2008). In contrast to the "body of Tibetan Monastery," the house in Hebrew medical text looks like a house as found in Venice or Padua at the time, additionally the painter included aspects of the traditional Jewish view of science (cf. Lepicard 2008).

Another architectural metaphor of the body has been published by the pioneer of infographics, Fritz Kahn (1888-1968). The illustration was meant to teach the interior of the body and its physiological functions to medical lay people. In "Man as Industrial Palace" (Der Mensch als Industriepalast: Sappol 2017, p. 113; Günther 1923) the human body is depicted in the shape of a German factory in the industrial design of the time. Metabolic processes of internal organs and their vascular connection are compared to the infrastructure of the chemical industry by using large machines and tanks connected by industrial tubes to present the organs. In a similar manner as the Japanese block prints, individuals are located inside the body. At crucial locations these industrial tools are supervised by human beings inside the body of the house. These human beings can be found at various locations, particularly in the brain or other locations with gateway functions such as the mouth or the pylorus between the stomach and duodenum. More research would be necessary to find out when the use of "working" human beings was introduced to demonstrate the functioning of internal organs in an entire human being, but the example of "Man as Industrial Palace" is certainly not the first of its kind, as the Asian examples of the two Japanese block prints were made around 1850 and the anonymous envoys of the king representing vulnerable parts in Tibetan medicine demonstrate. However, it seems that "Man as Industrial Palace" was also adapted by Chinese health authorities in 1933 when designing a children's health poster called "the human body is like a factory" (Sappol 2017, plate 10). In this image, human beings are only depicted inside the brain, one more indication that in the twentieth century the brain became regarded as more important than the heart.

The design of visual didactic material to impart medical knowledge to laypersons is an art in its own right, but describing medical discourse metaphorically within the medical community is another task. In the middle of the European nineteenth century concepts of humoral and solidar pathology were considered outdated and replaced by the concept of cellular pathology developed by Rudolf Virchow (1821-1902) on the basis of new microanatomical developments (histology). The pathologist, anthropologist, and politician Rudolf Virchow was certainly aware of the delicate use of metaphorical terms within scientific language, nevertheless he compared body cells to human individuals living in the body as citizens of state (cf.: Johach 2008, pp. 114-38).

7 https://publicdomainreview.org/2013/04/18/vesalius-and-the-body-metaphor/. 


\section{Military and Strategical Metaphors}

The Four Tantras are a medical text written "in a Buddhist world", comprising many Buddhist metaphors. Nevertheless, in several chapters nonreligious metaphors, such as strategic metaphors borrowed from nomadic, agricultural, or military experience, are applied. Particularly at the end of the 27th chapter of the Explanatory Tantra, the chapter on therapeutic principles where nine metaphorical strategies called "particular methods of healing" (khyad pavi gso tshul) are recommended (Bstan-vdzin-don-grub 2005, p. 128/3-15). These are allegories with strategies on how to proceed in different clinical situations. In the 28th chapter of the Explanatory Tantra, also entitled "particular methods of healing", these metaphors are revisited and explained using clinical procedures. In the Explanatory Tantra the connection between the content of a particular therapeutic principle is not straightforward, however Blo-bzang-chos-grags' text maintains that the connection is obvious. In Blo-bzang-chos-grags' text, strategic metaphors are structured with the help of an arboreal metaphor. A branch with nine leaves stands for the content of the final part in chapter 27 which describes the nine strategic metaphors. The tree structuring the content of chapter 28 has nine respective branches which are specified by almost a hundred leaves: metaphors within metaphors. These metaphors represent situations which may be observed and experienced in Tibetan life. Yang ga states that the section was adopted from Rgyud chung, which is regarded as an earlier text composed by the supposed author of the Four Tantras. According to him the passage does not correspond to any early medical works he analyzed (Yang Ga 2010, p. 177). As they seem to be of Tibetan origin, some examples will be discussed in somewhat more detail. I will refer to Blo-bzang-chos-grags' text as the metrical root text provides only a rudimentary level of information. The major commentaries are almost identical with the exception of some orthographic varieties (cf.: Sangs-rgyas-rgya-mtsho 1973, pp. 590/3-591/5; Blo-bzang-chos-grags 2005, pp. 112-113/9; Blo-gros-rgyal-po 2005, pp. 837/8-8/924). The first strategic metaphor is borrowed from the behavior of a cat: "Even if one does not properly understand the difference between hot and cold diseases, one is worried thinking: "is it something like this?". [In the case of] a disease one is not sure about, [one should be] like a cat: like the cat ${ }^{8}$ lurks for the mouse, the emergence (or, further development) is tested under "test administration" (sad mdav) and so on. When [the] diagnosis has been made, [the disease] is cured by the various drugs." The thermic quality is not mentioned in the Explanatory Tantra but in all major commentaries. The Explanatory Tantra only mentions the lurking cat but not the prey (the condition to be diagnosed). In Chapter 28 "test administrations" are presented, including tests to detect the humoral nature of a disorder or the chances of a success in the application of external therapies such as bloodletting and moxibustion.

The second principle is connected to a military metaphor and is in contrast to the first one: "If it is not necessary to investigate by means of 'test administration' as one has obtained certainty through diagnosis by inspection, palpitation and interrogation and thus gained a doubtless confidence, [the patient] will be treated directly with the respective drug which is comparable to a flag hoisted at an elevated level visible to all, such as the summit of a mountain." In Chapter 28, the "hoisted flag" is connected to the clear pronunciation of the etiology, method of treatment, and prognosis (cf. Parfionovitch et al. 1992, p. 241).

Another example of a strategic or military metaphor is to "guide an untamed horse along" if the diagnosis is correct but the disease cannot be treated directly. In the case of very serious diseases the image is more drastic: "Diseases of great seriousness should be treated with the four methods together: drugs, surgery, diet and behavior, as if an army in a narrow ravine would hit an enemy and kill him." In contrast to this, minor diseases should be treated gradually, and the four methods of diet, behavior, drugs, and surgery should be applied like rungs of a ladder (Blo-bzang-chos-grags

8 I take the term zhi po seems as haplographic misspelling for zhim bu "cat" caused by the juxtaposition of both byi la "cat" and byi ba "mouse" or "rat" in this passage. Ye-shes-gzungs writes in his early commentary byevu (little bird) instead of byi ba (Ye-shes-gzungs 2005, p. 210). 
2005, pp. 112/6-113/9; Parfionovitch et al. 1992, p. 241; Yuthok Yonten Gonpo 2008, pp. 264-65). The Illustrations to the Blue Beryl add a tenth, metaphor, borrowed from the 31st Chapter on the practicing physician: "To proceed without understanding the therapeutic principles is like shooting an arrow in the dark" (cf.: Parfionovitch et al. 1992, pp. 241: no 63, 245: no 49f.).

How do Tibetan metaphorical strategies with respect to "particular methods of healing" fit in to our contemporary approach to medicine and healing? The first metaphor of the lurking cat fits in with the daily medical dilemma that presented signs and symptoms are often associated with various diseases, ranging from the simple to threatening, whereby a precise differential diagnosis is not always immediately possible for a number of reasons. Even if it is not the most elegant therapeutic approach, in daily medical practice antibiotics or anti-inflammatory drugs are often prescribed as "test administration" (sad mdav) for the treatment of diseases of unclear origin, in the hope that the signs and symptoms will disappear. In many cases such an approach is successful, but the strategy of more or less nonspecific (test) prescriptions and observation may delay diagnosis and, in the worst case, treatment may be too late due to the progression of the disease. Nevertheless, observing the development of an illness in harmless cases may be the most appropriate strategy. The German technical jargon for this approach is "engmaschige Kontrolle" (close monitoring), whereby a tight net with tight interstices should not allow a "fish" (disease) to escape. In this case the physician keeps an eye on the development of a condition like a lurking cat to ensure that the time for necessary intervention is not missed.

The situation is almost the opposite in the case of the second Tibetan metaphor: to hoist a flag on the summit of a mountain if the diagnosis is clear and the physician should pronounce unambiguously the etiology, method of treatment and prognosis. Such a situation occurs in biomedicine after analyzing specific blood samples or when the initial suspicion is confirmed or invalidated by specific, partly invasive diagnostic techniques such as biopsies. Based on medical evidence, and depending on the stage (extent of spread) and grade (cellular appearance) of a malign tumor, the attending physician will inform the patient about treatment options and the associated side effects, risks and chances of success. Whether the strategy of "hoisting a flag" is appropriate in the context of a conversation about the prognosis of the disease must be questioned, often the individual development is different than the statistics suggest. The "hoisted flag" may produce relief for some patients because the physician demonstrates confidence and the patient gains understanding for the state of health. For other patients the "hoisted flag" may be frightening. Whether the communication strategy associated with this metaphor is helpful depends ultimately on the doctor's social competence.

The strategy to "guide an untamed horse along" is applied if the diagnosis is correct but the disease cannot be treated directly. In the Tibetan context, the strategy is connected to different forms of complex imbalances where the condition of a patient requires some preparatory application in order to reach a condition where direct treatment is possible. In biomedical practice this could be compared with neoadjuvant therapy, which aims to shrink a tumor prior to surgical intervention in order to reduce complications and morbidity connected with such radical procedures. This leads us to the next example of strategic metaphor saying that serious diseases should be treated with the four methods together-drugs, surgery, diet, and behavior-as if "an army in a narrow ravine would hit an enemy and kill him." Here, an aggressive disease is treated with an aggressive strategy. Depending on the type of "invasive" tumor the oncologist could be the "chief strategist in commanding an army" consisting of a combination of "weapons" including polychemotherapy, combined with an antiemetic and cortisone, supported by the recommendation of good nutrition and the instruction to exercise for one hour a day to prepare the patient for a major surgical intervention.

The final metaphorical example also involves the four Tibetan methods of healing, but minor diseases should be treated gradually, like the rungs of a ladder. Such an approach is often chosen for chronic diseases such as chronic back pain. The first step would be conservative therapy including physiotherapy involving special exercises, massages, or the application of warmth. If this does not help the administration of painkillers would be the next rung of on the ladder. Only in therapy-resistant cases or muscular weakness, and paralysis is surgical intervention would be the final next step. 
Tibetan medicine is not the only historical medical culture which applies military strategies. Historical and contemporary military metaphors may be found in various medical cultures and are adapted to the technical environment. Contemporary scholars of traditional Chinese medicine even compare concepts of classical Chinese medicine of numerous historical medical writers with the military strategies described in Sun Zi's Art of War, wherein diseases are compared to enemies and medicines to soldiers on various occasions (Wu et al. 1997). Geraldine Van Rijn-van Tongeren analyzed contemporary biomedical texts and found various military metaphors, especially with regard to cancer. He summarized conceptual military metaphors on tumor cells: "tumor cells invade and colonize, tumor cells are enemies and the basic conceptual metaphor: Cancer is war" (Van Rijn-van Tongeren 1997, p. 84). Although today, there are many options for the treatment of cancer, either as a curative measure or as a chronic condition in order to preserve a high quality of life. The aggression of some types of malign disease and the necessity of courageous medical efforts make it plausible to apply a military language such as the use of the term weapon for a therapeutic intervention.

The treatment of another modern disease is also often compared with war: HIV and AIDS. Although military metaphors are often used in the context of the viral infection, the form of metaphorical wording is more and more criticized as Judith Wilson Ross already asked in 1989 "Do We Really Want a War on Aids" (Ross 1989), and a number of scholars believe that military metaphors should be replaced by more peaceful wording (e.g., Nie et al. 2016). I would like to add that in specific acute medical situations a courageous procedure, which might be compared to terms borrowed from the military and police may be necessary, while in the case of chronic diseases a more "diplomatic" approach may be more helpful. There is no doubt that conceptual metaphors will ever be part of medicine, especially in public discourse and mass media. It might be seductive to compare viruses or cancer cells to terrorists or criminals (see Hanne and Hawken 2007, p. 95), but an awareness of the societal impact and danger of misinterpreting and misapplying such metaphors should inform and shape the politics of public health issues. Already Rudolf Virchow, for instance, warned against the use of body analogues in political debate (Johach 2008, p. 122).

\section{Metaphorical Names}

How about Tibetan medical terminology? In classical Tibetan language medical terms are often borrowed from the everyday religious or nomadic Tibetan life of various social classes. With the revitalization of Tibetan medicine and its encounter with biomedicine, a similar development is taking place as that of the process of defining an internationally binding biomedical nomenclature. Tibetan biomedical terminology has been shaped and coined rapidly in recent years (cf.: Sabernig 2017b, 2019b, 2019c). Both classical and modern Tibetan medical language makes use of various kinds of metaphorical name, as well as structural and conceptual metaphor. Not only in classical, but also in modern (biomedical) anatomy in Tibet, do we find biological, technical, military, architectural metaphor, and metaphors that refer to other body parts. All these biomedical terms were translated from international nomenclature via the Chinese language.

Classical Tibetan medical terminology for anatomical structures, pathologies or materia medica contains many metaphorical names often borrowed from nature and nomadic lifestyles. Although such metaphorical designations for anatomical structures are rarely mentioned in the Explanatory Tantra of the Rgyud bzhi itself, they can be found in the commentaries, and as designations for the corresponding structures on the thankas. It would be outside of the scope of this contribution to address the difficulty of biomedically identifying these names in great detail; a colorful plurality of different identifications and identification attempts can be found in my database on Tibetan Medical Terms. ${ }^{9}$ In the following I will present some typical ways of naming anatomical structures and exemplify the areas from which these metaphorical names are borrowed. The vast field of nature and biology often provides the

9 https://crossasia.org/de/service/crossasia-lab/tibetische-medizin-termini/. 
name of an anatomical structure. A muscle located on the upper arm is called "sheep tail" (lug gzhug); another muscle near the knee is called "black frog" (sbal nag); a tendon near the knee is "frog's head tendon" (sbal mgovi chu ba). Important vulnerable blood vessels on the trunk in the epigastric area are called "stag antler" (sha ru), "roe antler" (mon ru), or "snake eye" (sbrul mig). Not only terms related to nature, but also terms related to nomadic life, have found their way into the anatomical vocabulary of blood vessels: "donkey saddle crupper" (bong rmed), "hook" (vgreng bu), "horse's halter" (rta mthur), or "yak hair tent rope" (re thag) are typical examples. Blood vessels medial to the eyebrows have a military connotation: "golden spear" (gser mdung) and "silver spear" (dngul mdung). In all these examples, anatomical structures are associated with other objects because of their visual similarity and are named accordingly. A vulnerable blood vessel associated with the lung is called "blow of the conch shell" (dung $v b u d)$, an expression that alludes to the specific sound of air ventilation, apparently borrowed from monastic life (Parfionovitch et al. 1992, p. 199). Such metaphorical descriptions are by no means a Tibetan speciality, but can also be found in modern anatomical language, which is based on Latin and Greek and assembled in the internationally binding Terminologia Anatomica. Examples are metaphors referring to horsemanship, such as the "horse tail" (cauda equina) at the end of the spinal cord or the "Turkish seat" (sella turcica), a saddle-shaped depression in the middle cranial fossa, an allusion to the shape of the high military saddle of the Ottoman riders. ${ }^{10}$ Another biomedical example of a metaphor referring to the religious sphere is a structure shaped like a bishop's mitre and traditionally called valva mitralis. The term has been renamed as valva atrioventricularis sinistra, which is a good example of the tendency mentioned at the beginning of this article to replace metaphorical designations with topographical ones. However, the metaphorical term remains in clinical practice, for example as mitral insufficiency (ICD 10: 105, 134).

What applies to anatomical designations is also evident in Tibetan materia medica. It is not surprising that the names of plants and the ingredients of medicines are connected to nature, but numerous metaphorical names for species of plant are taken from the animal kingdom: "tiger meat" (stag sha) is classified as a herb, usually identified as Oxytropis sp. The same is true for "ram's horn" (lug ru: Pedicularis sp.) or "sheep eye" (lug mig: Aster sp.). The Explanatory Tantra mentions another herb called "horse hoof" (rta rmig) commonly identified as Viola sp. The illustrated pharmacopoeia by Vjam-dpal-rdo-rje presents Viola $s p$. with a small orthographic difference: rta mig would imply a "horse eye" (Vjam-dpal-rdo-rje 1971, p. 195) but seems to be a scribal error. It should be mentioned in passing that the "hoof of a horse" in its original meaning, spelled rta yi rmig pa, can also be found in the Rgyud bzhi in a section dealing with animal nails (Bstan-vdzin-don-grub 2005, p. 107/2). Another horse metaphor for a medical plant is "horse skin" (rta lpags) which has been identified using a large variance of botanical equivalents, most frequently Lamiophlomis sp. Metaphorical common biological names are frequently found in Europe, such as dandelion, literally "lion's tooth" from its toothed leaves, a translation of Medieval Latin dens leonis. ${ }^{11}$ The botanical name for the previously mentioned "ram's horn, the flower Pedicularis sp. refers to another animal: pediculus, the Latin name for louse.

Less frequent are metaphorical names of diseases in Tibetan medicine as many of them are associated with a specific humoral imbalance or are named according to the associated signs and symptoms. Rare metaphorical examples are names of dermatoses: sha bkra meaning literally "beautiful flesh" is often translated as vitiligo (Dash 1994, p. 168; Clark 1997, p. 119; Goldstein et al. 2001, p. 1089), a demonstration that white skin is regarded a beautiful. Another one is bas bldags which is described as "'licked by a cow', n. of a disease combined with the sensation, as if the skin has been licked off by a cow, cow-itch, cow-pox?" (Jaschke [1881] 2003, p. 367). Yet another skin disease is called glang shu, literally "ox-sore". According to Tsering Thakchö Drungtso and Tsering Dolma Drungtso $(2005$, p. 79) it means "psoriasis, eczema, or ichthyosis; a skin disorder which resembles that of the neck of an ox

10 An article solely on neurological metaphors in Tibetan medicine: (Sabernig 2019a).

11 https://www.etymonline.com/word/dandelion\#etymonline_v_757. 
driven on the field." Often it is translated simply as psoriasis (Goldstein et al. 2001, p. 210) or eczema (Dash 1994, p. 168), an improper normative practice of which was criticized by Florian Ploberger (2012, p. 210). In biomedicine there are fewer metaphorical terms in the field of symptoms and nosology, too, and they are found in more common language and also relatively frequently in the case on diseases associated with skin efflorescence. For example, scarlet fever is typically associated with a red tongue. This diagnostic hint is "strawberry tongue"; in German it is known as "Himbeerzunge" or "raspberry tongue". Other examples are the common names for varicella: "chicken pox" in English or "Windpocken" (verbatim "wind pox") in German. The terrible and now eradicated disease "small pox" caused by the Variola virus, received a less severe designation in order to distinguish it from the "Minster of Death," the other well-known scaring disease, "great pox", today known as syphilis (cf.: Barquet and Domingo 1997, p. 3).

\section{Good Metaphors-Bad Metaphors?}

In this article I introduced examples of metaphor found in the Explanatory Tantra. Are they abstract and valuable enough to convey an understanding for particular medical practices outside of the Tibetan context? How meaningful or misleading are these metaphors in medical thinking? Larger reflections on these questions may be outside the scope of this article but I would like to address some considerations. An important point in assessing the value of a metaphor in (Tibetan) medicine is the question of to whom a metaphor is addressed and the context in which it is used. What is of great value to historians and philologists can be completely out of place within a therapeutic conversation. What proves to be useful during a collegial discussion regarding scientific concepts or when teaching medical students could be inappropriate in the context of politics, mass media, or as a didactic tool to inform laypersons and vice versa. As we have seen, the comparison of internal organs with state organs or the locomotor system with architectural elements is a very common method of presenting medical content to the wider public. However, from a therapeutic point of view or for medical personnel these metaphors do not provide any significant additional information. Maybe that is the reason why Blo-bzang-chos-grags, whose text is mainly a didactic aid for students of Tibetan medicine to learn large quantities of medical content by heart, did not elaborate on these metaphors, which are addressed more to the broader public. In contrast, these simple and comprehensible metaphors are depicted in great detail in the Illustrations to the Blue Beryl and in the major commentaries. While the commentaries document medical scholars' different interpretations of the root text, the thangkas were not only designed as a didactic tool for medical students but also as a prestigious achievement presented to a broader public in the late seventeenth century in Tibet. On the other hand, Blo-bzang-chos-grags gave great attention to the strategic metaphors accompanying "particular methods of healing". These linguistic images are present in everyday Tibetan life, but are also abstract enough to illustrate different clinical situations also present in other medical cultures. If they are not taken literally, they offer helpful guidance to physicians within a biomedical setting. Nevertheless, some patients may find them inappropriate because of their subjective vulnerability. The problem with figurative language is that metaphor is useful when widening the horizon of possibilities and demonstrating the complex art of medicine but due to the individual subjectivity of the beholder different reflections and assessments can be concluded. Associations with "father figures", "military officers", "bodhisattvas", and "friends" are different from person to person and have the potential to provoke great emotion or misunderstanding. For some patients, a physician as a priest, soldier or teacher may be a good metaphor-for others it may be bad. In any case, the variety of different types of medical metaphor shows that medieval Tibetan scholars thought about different clinical situations or medical questions and allegories and were able to transform these problems into an abstract picture.

\section{Conclusions}

Metaphors are ubiquitous in Tibetan medical concepts. Different types of metaphors borrowed from various fields of life have been exemplified in this preliminary article. Even though the Four 
Tantras are regarded as a compilation of various text fragments assembled or translated from different medical traditions; the work was authored in the context of a deeply Buddhist society. Therefore, it is not surprising that the work comprises many conceptual metaphors typical for a Buddhist setting. Despite the pervasive presence of religion, Tibetan medicine should not be regarded as mainly theurgic as one can find many nonreligious metaphors. Many of them show cross-cultural characteristics and place medical thought in a societally comprehensible context. As can be learned from European models dating back to the renaissance era, it seems to be a universal human medical consideration that inner organs are compared to social or political authorities and that parts of the human locomotor system are compared with the architecture of a building. However, ornamenting details on illustrations usually show well-known features prevailing in the respective culture. Aside from metaphors related to the body, Tibetan medicine provides metaphors borrowed from worldly activities such as hunting, herding, tending a field, or fighting an enemy. It seems to be a distinctive trait of Tibetan medicine that metaphor in the terminology of anatomical structures and materia medica are often derived from nature and the animal world in particular. The orthography of Tibetan language also makes it possible that a small variance creates a new metaphor, as the examples of "horse hoof" (rta rmig) versus "horse eye" (rta mig) demonstrates.

Funding: This research received no external funding.

Acknowledgments: Special thanks go to Michael Balk for his general support and patience as well as to Catherine Kemp for her careful English language editing of this article. Thanks also go to the two reviewers for the thoughtful considerations.

Conflicts of Interest: The author, who is a physician, shiatsu practitioner, medical anthropologist, and scholar of Tibetan medicine, declares no conflicts of interest.

\section{References}

Barona, Josep Lluis. 1993. The Body Republic: Social Order and Human Body in Renaissance Medical Thought. History and Philosophy of the Life Sciences 15: 165-80. [PubMed]

Barquet, Nicolau, and Pere Domingo. 1997. Smallpox: The Triumph over the Most Terrible of the Ministers of Death. Annals of Internal Medicine 127: 635-42. [CrossRef] [PubMed]

BGT. 1985. Bod rgya tshig mdzod chen mo. Pe cin: Mi rigs dpe skrun khang.

Bkra-shis-dpal-ldan. 1985. Sum cu pavi sdong vgrems blo gsal mgul rgyan: Ram pa bkra shis dpal ldan gyis brtsa mas. Lha sa: Bod ljongs mi dmangs dpe skrun khang.

Blo-bzang-chos-grags [Dar-mo sman-rams-pa]. 2005. Bshad rgyud kyi sdong vgrems legs bshad gser gyi thur ma. In Legs bshad gser gyi thur ma bkav phreng mun sel sgron me. Bod kyi gso ba rig pavi gnav dpe phyogs bsgrigs dpe tshogs. Pe cin: Mi rigs dpe skrun khang, pp. 1-143.

Blo-bzang-chos-grags [Dar-mo sman-rams-pa]. 2017. Dpal ldan rtsa bavi rgyud dang bshad pavi rgyud kyi sdong vgrems dang rdevu vgrems gsal bshad = Zang yi li lun jie shuo [歲医理论解说]. La sa: Xi zang ren min chu ban she.

Blo-gros-rgyal-po. 2005. Rgyud bzhivi vgrel pa mes povi zhal lung. Stod cha. Pe cin: Mi rigs dpe skrun khang.

Bstan-vdzin-don-grub. 2005. Dpal ldan rgyud bzhi: Dpe bsdur ma. Rgyal khab krung lugs gso rig do dam cus mi rigs sman gzhung dpe sna dag bsgrigs. 1 vol. Pe cin: Krung govi bod rig pa dpe skrun khang.

Carter, Albert Howard. 1989. Metaphors in the Physician-patient Relationship. Soundings: An Interdisciplinary Journal 72: 153-64.

Childress, James F., ed. 1997. Practical Reasoning in Bioethics. Bloomington and Indianapolis: Indiana University Press.

Clark, Barry. 1997. Die Tibeter Medizin: Die Geheimnisse der Heilkunst aus den Hochtälern des Himalaja. Translated by Thomas Dunkenberger. Bern: O. W. Barth Verlag, Originally published as The Quintessence Tantras of Tibetan Medicine.

Cornu, Philippe. 2006. Dictionnaire Encyclopédique du Bouddhisme. Nouvelle edition augmentée. Paris: Éditions Du Seuil. 
Czaja, Olaf. 2007. The making of the Blue Beryl: Some Remarks on the Textual Sources of the Famous Commentary of Sangye Gyatso (1653-1705). In Soundings in Tibetan Medicine: Anthropological and Historical Perspectives. PIATS 2003: Tibetan Studies: Proceedings of the Tenth Seminar of the International Association for Tibetan Studies, 2003. Edited by Mona Schrempf. Leiden and Boston: Brill, pp. 345-71.

Dash, Vaidya Bhagwan. 1994. Encyclopaedia of Tibetan Medicine: Being the Tibetan Text of Rgyud bzhi and Sanskrit Restoration of Amṛta Hṛdaya Aștānga Guhyopadeśa Tantra and Expository Translation in English. 7 vols. Indian Medical Science Series No.-23; Delhi: Sri Satguru Publications.

Demaitre, Luke. 2012. The Isagoge and Five Other Texts of the Articella (1210-30?): Iohannitius (Hunayn ibn Ishaq al-Ibadi) and Others. In Hidden Treasure: The National Library of Medicine. Edited by Michael Sappol. Bethesda: National Library of Medicine, New York: Blast Books, pp. 22-25.

Garrett, Frances. 2007. Embryology and Embodyment in Tibetan Literature: Narrative Epistemology and the Rhetoric of Identity. In Soundings in Tibetan Medicine: Anthropological and Historical Perspectives. PIATS 2003: Tibetan Studies: Proceedings of the Tenth Seminar of the International Association for Tibetan Studies, 2003. Edited by Mona Schrempf. Leiden and Boston: Brill, pp. 411-25.

Goldstein, Melvin C., T. N. Shelling, and J. T. Surkhang, eds. 2001. The New Tibetan-English Dictionary of Modern Tibetan. Berkeley: University of California Press.

Günther, Hanns. 1923. Das Wunder in uns: Ein Buch vom menschlichen Körper für Jedermann. Zürich: Gretlein \& Co.

Gyatso, Janet. 2014. Buddhist Practices and Ideals in Desi Sangye Gyatso's Medical Paintings. In Bodies in Balance-The Art of Tibetan Medicine. Edited by Theresia Hofer. New York: Rubin Museum of Art, Seattle: University of Washington Press, pp. 198-220.

Gyatso, Janet. 2015. Being Human in a Buddhist World: An Intellectual History of Medicine in Early Modern Tibet. New York: Columbia University Press.

Hanne, Michael, and Susan J. Hawken. 2007. Metaphor for illness in contemporary media. Medical Humanities: Edition of the Journal of Medical Ethics 33: 33-93. [CrossRef] [PubMed]

Haverkamp, Anselm. 1998. Die paradoxe Metapher. Frankfurt am Main: Suhrkamp.

Haverkamp, Anselm, and Dirk Mende, eds. 2009. Metaphorologie: Zur Praxis von Theorie. Frankfurt am Main: Suhrkamp.

Jaschke, Heinrich August. 2003. A Tibetan-English Dictionary. Reprint. Richmond: Curzon Press. First published 1881.

Johach, Eva. 2008. Krebszelle und Zellenstaat: Zur medizinischen und politischen Metaphorik in Rudolf Virchows Zellularpathologie. Freiburg: Rombach.

King, Nancy M. P., Larry R. Churchill, and Alan W. Cross, eds. 1988. The Physician as Captain of the Ship: A Critical Reappraisal. Dordrecht: Reidel.

Lakoff, George, and Mark Johnson. 2003. Metaphors We Live by. With a new afterword. Chicago and London: The University of Chicago Press. First published 1980.

Lepicard, Etienne. 2008. An Alternative to the Cosmic and Mechanic Metaphors for the Human Body? The House Illustration in Ma'aseh Tuviyah (1708). Medical History 52: 93-105. [CrossRef] [PubMed]

Chandra, Lokesh. 1959-1961. Bod dang legs sbyar kyi mdzod = Tibetan-Sanskrit Dictionary: Based on a Close Comparative Study of Sanskrit Originals and Tibetan Translations of Several Texts. 12 vols. Śata-Pițaka: New Delhi International Academy of Indian Culture.

Meyer, Fernand. 1995. Theory and practice in Tibetan medicine. In Oriental Medicine: An Illustrated Guide to the Asian Arts of Healing. Edited by Jan Van Alphen and Anthony Aris. London: Serindia Publications, pp. 109-141.

Meyer, Fernand. 2003. The Golden Century of Tibetan Medicine. In Lhasa in the Seventeenth Century: The Capital of the Dalai Lamas. Edited by Francoise Pommaret. Translated by Howard Solverson. Leiden and Boston: Brill, pp. 99-117.

Michler, Michael, Jost Benedum, and Inge Michler. 1981. Einführung in die Medizinische Fachsprache: Medizinische Terminologie für Mediziner und Zahnmediziner auf Grundlage des Lateinischen und Griechischen, unter Mitarbeit von Inge Michler und Michael Michler, 2nd ed. Berlin/Heidelberg and New York: Springer.

Mkhyen-rab-nor-bu, and Byams-pa-phrin-las. 1987. Gso rig rgyud bzhivi sdong vgrems vdod vbyung nor buvi mdzod. Pe cin: Mi rigs dpe skrun khang.

Negi Jita Sain. 1993-2005. Bod skad dang legs sbyar gyi tshig mdzod chen mo = Tibetan-Sanskrit dictionary. 16 vols Varanasi: Central Institute for Higher Tibetan Studies. 
Nie, Jing-Bao, Adam Lloyd Gilbertson, Malcolm de Roubaix, Ciara Staunton, Anton van Niekerk, Joseph D. Tucker, and Stuard Rennie. 2016. Healing Without Waging War: Beyond Military Metaphors in Medicine and HIV Cure Research. The American Journal of Bioethics 16: 3-11. [CrossRef] [PubMed]

Oliver, Michael, Alexander Woywod, Aimun Ahmed, and Imran Saif. 2011. Organ donation, transplantation and religion. Nephrol Dial Transplant 26: 437-44. [CrossRef] [PubMed]

Pad-ma-dkar-po [Blo-gsal-dbang-po]. 2007. Rgyud bzhivi vgrel ba gzhan la phan pavi gter. In Bshad pavi royud kyi levu nyi shu pa sman gyi nus pa bstan pavi tshig gi don gyi vgrel ba mes povi dgongs rgyan zhes bya ba bzhugs so. Rgyud bzhivi vgrel ba gzhan la phan pavi gter. Bod kyi gso ba rig pavi gnav dpe phyogs bsgrigs dpe tshogs 52. Pe cin: Mi rigs dpe skrun khang.

Parfionovitch, Yuri, Gyurme Dorje, and Fernand Meyer, eds. 1992. Tibetan medical Paintings: Illustrations to the 'Blue Beryl' treatise of Sangs rgyas Rgya mtsho (1653-1705). London: Serindia Publications.

Ploberger, Florian, ed. 2012. Wurzeltantra und Tantra der Erklärungen aus "Die vier Tantra der tibetischen Medizin". Ulrike Derx, and Florin Ploberger, transs. Schiedlberg: Bacopa.

Polzenhagen, Frank, Zoltan Kövecses, Stefanie Vogelbacher, and Sonja Kleinke, eds. 2014. Cognitive explorations into metaphor and metonymy. Frankfurt am Main: Peter Lang.

Pormann, Peter, and Emilie Savage-Smith. 2007. Medieval Islamic Medicine. Washington, DC: Georgetown University Press.

Priya vrat sharma, ed. 2000. Suśruta-saṃhitā. Haridas Ayurveda Series 9/2; Varanasi: Chaukhambha Visvabharati, vol. 2.

Prost, Audrey. 2008. Precious Pills: Medicine and Social Change among Tibetan Refugees in India. Epistemologies of Healing. New York: Berghahn Books, vol. 2.

Reighter, Cheryl Anne. 2000. Riding a Wild Horse: The Role of Metaphor in Tibetan Medicine. Ph.D. dissertation, University of Colorado Boulder, Boulder, CO, USA.

Ross, Judith Wilson. 1989. The Militarization of Disease: Do We Really Want a War on Aids? Soundings: An Interdisciplinary Journal 72: 39-58.

Sabernig, Katharina. 2002. Tiger bändigt Drachen: Eine Anleitung zum besseren Verständnis für die Traditionelle Chinesische Heilkunde insbesondere der fünf Wandlungsphasen. Bacopa: Schiedlberg.

Sabernig, Katharina. 2014. Medical Murals at Labrang Monastery. In Bodies in Balance-The Art of Tibetan Medicine. Edited by Theresia Hofer. New York: Rubin Museum of Art, Seattle: University of Washington Press, pp. 221-25.

Sabernig, Katharina. 2017a. Visualisierte Heilkunde: Eine medizinanthropologische Studie zur Identifizierung der Wandbilder der medizinischen Fakultät des Klosters Labrang. Ph.D. dissertation, University of Vienna, Vienna, Austria.

Sabernig, Katharina. 2017b. Vulnerable Parts: Locating and Defining Vital Areas of the Body in Tibetan Medicine. Asian Medicine 12: 86-118. [CrossRef]

Sabernig, Katharina. 2018. Illustrations depicting the environment around the mythical city of Tibetan medicine. In Modernizing the Tibetan Literary Tradition. Edited by Pavel Grokhovsky. Saint Petersburg: St. Petersburg University Press, pp. 169-80.

Sabernig, Katharina. 2019a. The Tree of Nosology. In Cultural Systems of Classification: Sickness, Health and Local Epistemologies. Edited by Ulrike Steinert. London: Taylor \& Francis, forthcoming.

Sabernig, Katharina. 2019b. Neurological Metaphors in Tibetan Medical Language. In Grenzgänge zwischen Medizin, Ethnologie und Psychologie: Für Ekkehard Schröder zum 75. Geburtstag. Edited by Katarina Greifeld, Wolfgang Krahl, Hans Jochen Diesfeld and Hannes Stubbe. Berlin: Curare, Zeitschrift für Medizinethnologie.

Sabernig, Katharina. 2019c. Visceral Anatomy as Depicted in Tibetan Medicine. In Knowledge and Context in Tibetan Medicine. Edited by William McGrath. Leiden and Boston: Brill, forthcoming.

Salguero, Pierce. 2010. Mixing Metaphors: Translating the Indian medical Doctrine Tridoṣa in Chinese Buddhist Sources. Asian Medicine 6: 55-74. [CrossRef]

Salguero, Pierce. 2014. Translating Buddhist Medicine in Medieval China. Philadelphia: University of Pennsylvania Press.

Sangs-rgyas-rgya-mtsho. 1973. Bai dūr snion po: Being the text of "Gso ba rig pa'i bstan bcos sman bla' $i$ dgons rgyan rgyud bzi'i gsal byed Bai dūr snion po'i ma lli ka"; Sde-srid Sansrgyas-rgya-mtsho's Detailed Synthetic Treatise on the Rgyud-bzi, the Fundamental Exposition of Tibetan Ayurvedic Medicine. 4 vols. Leh: T. Y. Tashigangpa, Reproduced from a print of the 1888-92 blocks preserved in the Lha sa lcags po ri rig byed 'gro phan gling. 
Sappol, Michael, ed. 2017. Body Modern: Fritz Kahn, Scientific Illustration and the Homuncular Subject. Minneapolis and London: University of Minnesota Press.

Savage Smith, Emilie. 2002. Galen's Lost Ophthalmology and the Summaria Alexandrinorum. In The Unknown Galen. Edited by Vivian Nutton. London: Institute of Classical Studies, School of Advanced Study, University of London, pp. 121-38.

Shirasugi, Etsuo. 2007. Essay on Anatomy: Envisioning the inner body during the Edo period in Japan: Inshoku yojo kagami (Rules of Dietary Life) and Boji yojo kagami (Rules of Sexual Life). Anatomical Science International 82: 46-52. [CrossRef] [PubMed]

Siegler, Mark. 1997. Metaphors and Models of Doctor-patient Relationship: Their Implications for Autonomy. In Practical Reasoning in Bioethics. Edited by James F. Childress. Bloomington and Indianapolis: Indiana University Press, pp. 44-55.

Tajer, Carlos D. 2012. Thinking Medicine Metaphorically. Argentine Journal of Cardiology 80: 485-93.

Taube, Manfred. 1981. Beiträge zur Geschichte der medizinischen Literatur Tibets. Sankt Augustin: VGH Wissenschaftsverlag.

Tsering Thakchö Drungtso [Tshe-ring-thag-gcod], and Tsering Dolma Drungtso [Tshe-ring-sgrol-ma]. 2005. Bod lugs sman rtsis kyi tshig mdzod bod dbyin shan sbyar = Tibetan-English Dictionary of Tibetan Medicine and Astrology. Revised and enlarged edition. Dharamsala: Drungtso Publication.

Tzohar, Roy. 2018. A Yogācāra Buddhist Theory of Metaphor. Oxford: University Press.

Unschuld, Paul Ulrich. 1980. Medizin in China: Eine Ideengeschichte. München: Verlag C. H. Beck.

Van Rijn-van Tongeren, Geraldine W. 1997. Metaphors in Medical Texts. Amsterdam and Atlanta: Rodopi.

Vercammen, Dan. 1995. Theory and Practice of Chinese Medicine. In Oriental Medicine: An Illustrated Guide to the Asian Arts of Healing. Edited by Jan Van Alphen and Anthony Aris. London: Serindia Publications, pp. 157-95.

Vjam-dpal-rdo-rje [of Mongolia]. 1971. An Illustrated Tibeto-Mongolian Materia Medica of Ayurveda. Edited by Lokesh Chandra. New Delhi: International Academy of Indian Culture.

Wu, Rusong, Hongtu Wang, and Ying Huang. 1997. Sun Zi's Art of War and Health Care = Sun zi bing fa yu yang sheng zhi bing [孙子兵法与养生治病]. Military Science and Medical Science. Beijing: New World Press.

Yang Ga. 2010. The Sources for the Writing of the Rgyud bzhi, Tibetan Medical Classic. Doctoral dissertation, Harvard University, Cambridge, MA, USA.

Ye-shes-bzang-po. 2007. Bshad pavi rgyud kyi gnas lugs levuvi vgrel bshad rag tho dam pa snga mavi zhal rgyun. In Gtsang sman pavi sman yig phyogs bsgrigs. Bod kyi gso ba rig pavi gnav dpe phyogs bsgrigs dpe tshogs. Pe cin: Mi rigs dpe skrun khang, pp. 155-81.

Ye-shes-gzungs. 2005. Bdud rtsi snying po yan lag brgyad pa gsang ba man ngag gi rgyud las bshad pavi rgyud kyi vgrel pa vbum nag gsal bavi sgrong me zhes bya ba bzhugs so. In Vbum nag gsal sgron zhes bya ba bzhugs so/vbum chung gsal sgron zhes bya ba bzhugs so. Bod kyi gso ba rig pavi gnav dpe phyogs bsgrigs dpe tshogs. Pe cin: Mi rigs dpe skrun khang, pp. 1-234.

Yuthok Yonten Gonpo. 2008. The Root Tantra and the Explanatory Tantra from the Secret Quintessential Instructions on the Eight Branches of the Ambrosia Essence Tantra. Translated by Translation Department. Dharamsala: Men-Tsee-Khang.

Yuthok Yonten Gonpo. 2011. The Subsequent Tantra: From the Four Tantras of Tibetan medicine. Translated by the Translation Department. Dharamsala: Men-Tsee-Khang.

(C) 2019 by the author. Licensee MDPI, Basel, Switzerland. This article is an open access article distributed under the terms and conditions of the Creative Commons Attribution (CC BY) license (http://creativecommons.org/licenses/by/4.0/). 